functions. The question then arises as to whether modulation of receptor levels is restricted to interhormonal regulation or whether this phenomenon is even more widespread. Raff (News and Views 259, 265; 1976) has reviewed the general topic of regulation of receptors, particularly where it concerns immunological sensitivity and Jymphocyte maturation. A recent paper from Munck's group (Smith et al. Nature 267,$523 ; 1977$ ) is therefore significant in this context since it suggests that non-hormonal signals could also modulate hormone receptors. These workers studied glucocorticoid receptors during mitogen (concanavalin A) stimulation of human lymphocytes and noted that blasit transformation and mitosis is associated with a striking increase in the number but not nature of receptor sites per cell. How such a modulation of receptor numbers is brought about remains unknown, but their observations explain quite nicely the increased sensitivity to glucocorticoid hormones known to be brought about by mitogenic stimulation of lymphocytes and may also be relevant to the general question of how steroid hormones control the immune response.

\section{Pollen analysis at INQUA}

\section{from Paul Colinvaux}

The X INQUA Congress was held in August, 1977 at the University of Birmingham. Pollen analysis was one of the many topics bearing on Quaternary research that were discussed.

FOR most of its existence, pollen analysis has been a tool of other disciplines; being used to age strata, to supply the temperatures of past times, to serve phytosociologists as they mapped the supposed movements of plant associations through millennia.

Time stratigraphy is now provided by Quaternary geology and isotope chemistry. Oceanic sediments now provide maps of past global climates. The press of contemporary ecological theory is to question strongly the validity of many former ideas about the integrity of plant communities. These developments allow pollen analysis to be used in more exhilarating ways, and the new ways are now taking hold.

One group of pollen analysts is interested in the ancestry of the remarkable complexity of the deciduous forests of Eastern North America. For several years this school has been

Paul Colinvaux is at Ohio State University. growing more confident in its insistence that the forest associations of Eastern America are comparatively recent assemblages of plants without the integrity, or persistence as communities, required by classical plant sociology. This school has used the pollen record to infer the responses of plant populations to known climatic change, borrowing climatic data from other disciplines. At the conference these analysts were confident that their case is made. Pollen analysis shows that plant associations beyond the front of the Wisconsin ice were different from all the associations we know today; and the tundras, prairies, and forests that replaced each other on the lands once held by ice were always critically different from the modern assemblages.

However, INQUA also saw reports of the refined use of pollen data to infer past climates. Fossil pollen assemblages are being compared with many surface samples, and the data are then being analysed with multivariate statistical techniques. It sounds like using principal components and canonical series to do what was once done by eyeball fits, but the approach is vitally different. The old way was to seek modern plant associations that were homologous with past communities and to graft on to those past communities the climate under which the supposed modern homologue was living. The new way is to select from ancient pollen spectra only those taxa found in comparable numerical abundance in surface samples, and then to compare the distributions of this select array with distributions of the same plants in historic times. There is in this no dubious assumption about the integrities or environmental requirements of whole plant communities; the only biological assumption is the respectable Darwinian one that niche requirements of each species do not change very much. Climatic reconstructions of this kind follow the methods that have been used by students of foraminifera in deep sea cores to reconstruct ancient water temperatures. INQUA saw several elegant papers using this approach. At INQUA, therefore, pollen analysis was used both to refute the existence of permanent plant communities and to improve the resolution of the climatic inferences that can be drawn from pollen.

All pollen analysts at INQUA drew comfort from the certainty that the oxygen isotope record of deep sea cores yields a chronology of the volume of global ice. The isotope record is not of ocean temperature, as was thought only a short while ago, but of glacial ice. It tells us nothing about world climate, other than the existence of ice itself, but it is a global time stratigraphy and it must loosely relate to the particular climate of any one place. All pollen analysts have found themselves asking 'Are the local developments of vegetation that I see in step with the curve defining relative ice volume?' INQUA saw the first data relating isotope measurements to pollen in the same samples of offshore cores, revealing a gratifyingly close synchrony between changes in coastal forests and the volume of distant glaciers. A climatic linking mechanism is inescapable.

There were the expected developments in longer records and explorations in lesser-known parts of the world. Those with the long cores will look to the ice-volume curves to help with their time-stratigraphies and the first attempt of this kind to date long cores with the help of the ice volume curve was reported -a splendid long record from Searls Lake in California. The still very uncertain possibilities of remanent magnetism are also being explored to date pollen records back to the postulated Blake Event and beyond at Japanese Biwa, in Alaskan Imuruk Lake, and for the superb section from Grande Pille in France. The next INQUA may well see some ambitious reconstructions from these places describing the shufflings of plant species on single sites for more than 100,000 years.

The number of pollen records from the rest of the world grows slowly but steadily. Mapping the past in the Soviet Union continues as pollen analysts follow the completed map of the Quaternary deposits of that vast country, taking particular note of regions where archaeologists are active. But in lower latitudes where we need to know most there is still least to report. From the Indo-Pacific there are a few scattered records but from the South American equator near silence, particularly from the Amazonian basin. A member of the CLIMAP team at INQUA was heard to remark that he had had to infer the Wisconsin age vegetation of Amazonia from a paper on the modern distribution of bird species.

Yet in Africa there is progress, as papers come from Ethiopia and Chad, the lakes of the Rift, the dry basins of Sahara, and an array of stations in the South. But this African work shows how formidable are the difficulties of pollen analysis in tropical regions where the crucial species leave little pollen and where the species list is huge. As D. A. Livingstone remarked, deep in Tanganyka and the other lakes of the Rift lies a detailed history of the vegetation of this cradle of humanity since the pliocene and beyond, but he despaired of seeing it read in his lifetime. 